\title{
PENGEMBANGAN WAKAF TUNAI BERBASIS UMRAH DI PONDOK PESANTREN TA'MIRUL ISLAM SURAKARTA
}

\author{
Qi Mangku Bahjatulloh \\ Institut Agama Islam Negeri (LAIN) Salatiga \\ bahjatulloh@gmail.com
}

\begin{abstract}
The aim of this study was to determine the cash of waqf development umrah and suitability based on sharia-based cash waqf umrah in Ta'mirul Islamic boarding school. This study is a field research with qualitative methods. The object of this study is the agency of Haij and Umrah AlMabrur Islamic Boarding School of Ta'mirul Islam Surakarta. The method of analysis was comparation analysis, to re-examine its suitability with aspects of comparison that is pillars, of waqf terms, and conditions MUI. As well as using SWOT analysis to determine the factors that needs to be strategic. Based on the findings in this study, it can be concluded that the cash of waqf Umrah is a charity-based effort to serve the pilgrims in the Haij pilgrimage and of waqf as well as cash. This effort combines "tijari" contract models and "tabarru" contract models, in which convey with sharia.
\end{abstract}

Keywords: Cash Waqf, Tijari Contract, Tabarru Contract

\begin{abstract}
Abstrak
Tujuan dari penelitian ini adalah untuk mengetahui pengembangan wakaf tunai berbasis umrah dan kesesuaian syariah wakaf tunai berbasis umrab di Pondok Pesantren Ta'mirul Islam. Penelitian ini merupakan penelitian field research dengan metode kualitatif. Objek penelitian ini adalah biro haji dan umroh Al Mabrur Pondok Pesantren Ta'mirul Islam Surakarta.Metode analisis penelitian ini menggunakan comparation analysis, untuk memeriksa kembali kecocokannya dengan aspek pembanding, yaitu rukun, syarat wakaf, dan ketentuan MUI. Serta menggunakan analisis SWOT untuk mengetahui faktor-faktor strategis yang perlu. Berdasarkan temuan dalam penelitian ini, maka dapat disimpulkan babwawakaf tunai berbasis umroh adalah amal usaha untuk melayani jamaah dalam ibadah umroh dan haji serta wakaf tunai.Amal usaha ini menggabungkan model akad tijari dan aqad tabarru, yang praktiknya sesuai dengan syariah.
\end{abstract}

Kata Kunci: Wakaf Tunai, Akad Tijari, Aqad Tabarru 


\section{Pendahuluan}

Munculnya problem sosial dan tuntutan kesejahteraan ekonomi yang berada di tengah-tengah masyarakat Indonesia sekarang ini menjadikan wakaf tunai menjadi sangat strategis untuk di kembangkan dan dikaji, sebab selain sebagai salah satu aspek ajaran Islam yang berdimensi spiritual, wakaf tunai atau wakaf uang juga merupakan ajaran yang menekankan pentingnya kesejahteraan ekonomi yang dimensi sosial dan kesejahteraan umat. Wakaf juga termasuk ajaran Islam yang menyangkut kehidupan bermasyarakat dalam rangka ibadah ijtima'iyah atau ibadah sosial(Ghafur, 2006).

Berbagai macam cara yang telah dilakukan pemerintah untuk mengatasi masalah kesejahteraan ekonomi di Indonesia, diantaranya melalui JPS (Jaringan Pengaman Sosial) serta berbagai sumbangan dari dalam dan luar negeri. Pemerintah sendiri tampaknya cukup kesulitan untuk mengatasi masalah ini mengingat terbatasnya dana yang tersedia dalam APBN. Salah satu alternatif yang diharapkan untuk mengatasi masalah kesejahteraan ekonomi di Indonesia adalah adanya partisipasi aktif dari pihak non pemerintah, yang dalam hal ini adalah masyarakat.Masyarakat, khususnya golongan kaya, memiliki kemampuan untuk membantu meringankan penderitaan masyarakat miskin. Apabila potensi masyarakat (kaya) ini dapat dikoordinasikan serta dikelola dengan baik, maka hal ini dapat memberikan alternatif kontribusi penyelesaian positif atas masalah kemiskinan tersebut di atas.

Data Badan Pusat Statistik (BPS) No. 06/01/Th. XVII, 2 Januari 2014 menerangkan bahwa Indonesia dalam sudut pandang ekonomi masuk dalam 16 negara terbesar di dunia karena Indonesia termasuk Negara yang kaya dan memiliki wilayah yang luas dengan jumlah penduduk nomor empat terbanyak di dunia. Akan tetapi jika dilihat dari pendapatan per kapita yang mencapai US $\$ 4.900$, ternyata kesejahteraan masyarakat Indonesia masih rendah karena baru menempati ranking ke-126 di dunia, jauh tertinggal dibandingkan Malaysia yang ada di peringkat 69, dan Thailand 92 dan Tiongkok di peringkat 93. Bahkan kita masih di bawah Sri Lanka yang menempati ranking 116. Rendahnya tingkat kesejahteraan penduduk negara, ditunjukan dengan fakta bahwa jumlah penduduk 
miskin masih tinggi, yaitu sebanyak 28,55 juta atau 14 persen. Ditambahkan, sebanyak 63 persen penduduk miskin Indonesia berada di pedesaan dan mayoritas adalah petani dan nelayan. Sementara jumlah pengangguran masih sekitar tujuh persen dari seluruh angkatan kerja.Jelas kondisi ini adalah bukti bahwa bangsa Indonesia masih menghadapi sejumlah masalah mendasar berupa berbagai kesenjangan sosial dan ekonomi, serta kesenjangan antar daerah dan antar kawasan, serta infrastruktur yang tidak merata. Problem sosial dan tuntutan kesejahteraan ekonomi yang berada di tengah-tengah masyarakat Indonesia sekarang ini menjadikan wakaf tunai menjadi sangat menarik untuk dikaji dan dikembangkan, sebab selain sebagai aspek ajaran Islam yang berdimensi spiritual, wakaf uang juga ajaran yang menekankan pentingnya kesejahteraan ekonomi dimensi sosial dan kesejahteraan umat.

Lahirnya Undang-Undang Republik Indonesia No. 41 tahun 2004 tentang Wakaf mempertegas untuk memberdayakan wakaf yang merupakan salah satu instrumen dalam membangun kehidupan sosial ekonomi umat Islam.Kehadiran Undang-undang wakaf ini menjadi momentum pemberdayaan wakaf secara produktif, sebab di dalamnya terkandung pemahaman yang komprehensif dan pola manajemen pemberdayaan potensi wakaf secara modern.Namun, menurut (Rahardjo, 1986:117) usaha ke arah itu jelas bukan pekerjaan yang mudah.Semua membutuhkan daya kreatifitas dan usaha yang tanpa henti.

Ada kekuatan besar umat yang belum terberdayakan secara maksimal dalam membantu ekonomi nasional.Kekuatan itu adalah semangat filantropi umat Islam.Pengelolaan derma uang bagi umat Islam dalam hukum positif di Indonesia dipayungi dua undang undang yakni undang undang pengelolaan zakat dan UU wakaf. Pengelolaan zakat diatur dalam UU No. 38 tahun 1999 tentang pengelolaan zakat kemudian diperbaharui dengan UU No. 23 tahun 2011 tentang pengelolaan zakat (selanjutnya disingkat UU Zakat). Pengelolaan wakaf diatur dalam UU No. 41 tahun 2004 tentang Wakaf. Pengelolaan zakat dan wakaf sebagai instrument pengelolaan derma di masyarakat sudah menjadi wilayah hukum positif di Indonesia. Pengelolaan zakat dan wakaf yang dilakukan oleh masyarakat secara tidak langsung mencerminkan perilaku 
masyarakat terhadap hukum positif di Indonesia.Lembaga filantropi diharapkan mampu memiliki manajemen modern, profesional, dan transparan.Tidak hanya sisi manajemen, lembaga filantropi juga hendaknyameningkatkan program-program pemberdayaan masyarakat miskin, misalnya program peningkatan kemampuan dan keterampilan kerja/usaha melalui pendidikan dan latihan-latihan kerja, perluasan jaringan usaha networking, dan bantuan modal kerja.

Studi ini dilakukan untuk mengetahui bagaimana pengelolaan dan pengembangan serta model manajemen pengelolaanwakaf tunai berbasis umrah dan mengetahui analisis kesesuaian syariah wakaf tunai berbasis umrah yang berjalan di Pondok Pesantren Ta'mirul Islam.

\section{Pengertian Wakaf}

Wakaf secara etimologi berasal dari kata waqafa-yaqifu yang artinya berhenti (Warson, 1984:1683).Kata ini sering disamakan dengan al-tabbis atau al-tasbil yang bermakna al-habs 'an tasharruf, yakni mencegah dari mengelola.Menurut Jumbur ulama, wakaf adalah menahan harta yang memungkinkan untuk mengambil manfaat dengan tetapnya harta tersebut serta memutus pengelolaan dari wakif dan selainnya dengan tujuan mendekatkan diri kepada Allah (Zuhayli, t.th.: 7601). Menurut al-Kabisial (2004: 61), definisi yang lebih singkat dan padat (jami' mani) adalah definisi Ibnu Qudamah yang mengambildari potongan hadis Rasulullah in syita habasta wa tashaddaqta biha. Pendapat ini juga menjadi acuan dalam definisi wakaf dalam pandangan Tabung Wakaf Indonesia (Saidi, 2007: 2).Dalam hukum Islam, wakaf berarti menyerahkan suatu hak milik yang tahan lama (zatnya) kepada seseorang atau nadzir (penjaga wakaf), baik berupa perorangan maupun badan pengelola dengan ketentuan bahwa hasil atau manfaatnya digunakan untuk hal-hal yang sesuai dengan syariat Islam (Sudarsono, 2004).

Penggalian hukum wakaf telah dilakukan ulama dengan mengelaborasi pesan-pesan implisit dalam Alquran dan bersandar pada teks-teks hadis Rasulullah SAW.Beberapa dalil yang menjadi landasan hukum waqaf antara lain, ayat Al Quran surat Ali Imran 
ayat 92, dimana, salah satu shahabat Nabi SAW, Abu Thalhah setelah mendengar ayat ini langsung mewaqafkan tanahnya yang paling dicintainya di Bairuja 'Hadis riwayat Imam Muslim, Apabila meninggal anak. Adam, maka putuslah amalnya kecuali dari tiga perkara; shadaqah jariyah, ilmu yang bermanfaat, dan anak yang shaleh yang selalu mendoakannya" Shadaqah dalam hadis diatas diartikan oleh para ulama dengan waqaf.

Miftahul Huda (2011) dalam penelitiannya,Mekanisme Kerja Bersama Antara Nazir dan Lembaga Keuangan Syariah Penerima Wakaf Uang(LKS-PWU) Dalam Menggalang Wakaf Uang Perspektif Manajemen Fundrising.Menunjukkan tiga pola penggalangan wakaf (fundrising) yang dilakukan para nazhir ketiga lembaga itu. Tiga pola itu adalah: (1) Pola menghimpun wakaf dari sumber-sumber yang tersedia, baik dari masyarakat perorangan, perusahaan, maupun pemerintah, (2) Pola menciptakan produktifitas aset-aset wakaf yang ada dengan cara membangun unit-unit usaha dan ekonomi, pertanian dan perkebunan, serta mengefektifkan bangunan wakaf yang menghasilkan pendapatan bagi nazhir, dan,(3) Pola memberdayakan distribusi hasil wakaf untuk masyarakat umum (manquf alaib) dengan memaksimalkan program penyaluran hasil wakaf yang memberdayakan baik finansial maupun non-finansial, seperti pendidikan dan kajian Islam, pelayanan sosial, dan pemberdayaan sosial ekonomi masyarakat bagi kesejahteraan mereka.

Fahmi Medias (2010) juga berpendapat dalam penelitiannya bahwa dimasukkannya wakaf uang dalam perundangan-undangan Republik Indonesia melalui Undang-Undang No 41 tahun 2004, peluang baru bagi umat Islam Indonesia untuk mengelola dan mengembangkan suatu potensi dana umat yang cukup besar dengan produktif dan profesional dalam meningkatkan kesejahteraan ekonomi kaum muslimin dan melepaskan umat Islam dari kemiskinan. Bahkan dimungkinkan, wakaf uang bisa menjadi jalan alternatif untuk melepas ketergantungan bangsa ini dari lembagalembaga kreditor multilateral sekaligus menstimulasi pertumbuhan ekonomi Indonesia khususnya ekonomi Islam.

Dalam penelitian Suhairi (2011) Implementasi Wakaf Uang (Studi terhadap Persepsi Umat Islam Kota Metro Serta Kesiapan 
Bank Syariah Mandiri dan Kementerian Agama Kota Metro), dalam penelitian ini mengungkap bahwa :(1) Umat Islam kota Metro yang notabene mayoritas bermazhab Syafi'i, tapi dalam hal wakaf uang mayoritas menyatakan kebolehan dan setuju dengan wakaf uang, sangat prospektif dan potensial. (2) Wakaf uang dikalangan umat Islam Kota Metro belum diketahui dan dipahami secara baik, hal tersebut mengingat belum tersosialisasikannya wakaf uang. (3) Bank Syariah Mandiri (BSM) cabang Kota Metro pada hakikatnya sudah siap melaksanakan wakaf uang, hal tersebut berdasarkan adanya surat edaran operasi dari BSM pusat tentang penerimaan wakaf uang nazhir Badan Wakaf Indonesia, hanya saja pihak BSM belum menyiapkan blangko-blangko serta sertifikat wakaf uang dengan alasan karena belum ada yang mewakafkan uang serta belum mengumumkan kepada publik akan keberadaannya sebagai LKS-PWU. (4) Kementerian Agama kota Metro sama sekali belum menyiapkan formulir pendaftaran dan hal-hal lain yang perlu disiapkan berkaitan dengan implementasi wakaf uang, bahkan yang ironis belum menerima PMA Nomor 4 tahun 2009 dan Keputusan Dirjend Bimas Islam tentang Model, Bentuk dan Spesifikasi Formulir Wakaf Uang.

Penelitian tentang wakaf yang dilakukan M Ikhsanudin (2012) dalam Optimalisasi Wakaf Produktif Bagi Lembaga Pendidikan Dan Ormas Islam Di Indonesia, dengan pendekatan kualitatif menyimpulkan bahwa Wakaf produktif berperan sentral dalam peningkatan taraf ekonomi masyarakat. Oleh karena itu, Ormas Islam dan Lembaga pendidikan perlu memasyarakatkan, mengelola dan mengembangkan wakaf produktif secara profesional. Ada beberapa langkah-langkah strategis yang perlu dilakukan oleh Lembaga Pendidikan dan Ormas Islam di Indonesia untuk mengembangkan wakaf produktif yaitu: (1) Membentuk tim pengkajian untuk pengembangan wakaf produktif dan wakaf tunai. Wakaf produktif dan wakaf tunai bisa berjalan dengan baik kalau ada pengkajian secara serius dari sebuah tim yang mumpuni dan profesional yang melibatkan orang dari multidisplin ilmu baik ahli ilmu ekonomi, hukum, figh, ilmu tanah dan lainnya yang bersinergi dalam menyusun, mengkaji dan mengembangkan rencana wakaf produktif dan wakaf tunai. (2) Menyelesaikan persoalan tanah 
wakaf dan mensertifikasi untuk pengembangan wakaf produktif. Tanpa landasan hukum yang kuat terhadap status tanah, akan memunculkan friksi dikemudian hari. Oleh karena itu, aspek legal formal merupakan salah satu prioritas sebelum perencanaan usaha wakaf produktif. (3) Membuat langkah-langkah program untuk pengembangan wakaf produktif. Langkah-langkah ini mulai tahap persiapan, analisis SWOT agar setiap tahapan program bisa terlaksana dengan baik.(4) Melakukan audiensi dan studi banding pengelolaan wakaf produktif kepada lembaga-lembaga yang sudah cukup mapan mengelola tanah produktif, seperti Pondok Modern Darussalam Gontor, Dompet Du'afa' Republika, Badan Wakaf Sultan Agung Semarang, atau sampai keluar negeri seperti Badan Wakaf Universitas al-Azhar.(5) Membuat social enterprise planningpengembangan wakaf produktif. Dalam fase ini, nadhirharus serius mempersiapkan skenario usaha dari tahap perencanaan usaha, hingga implementasi usaha.(6) Melakukan lobbying dan membangun networkingpembiayaan wakaf produktif baik dengan institusi dalam negeri (Direktorat Pemberdayaan Wakaf Kementrian Agama R.I., maupun Badan Wakaf Indonesia/BWI) dan lembaga perwakilan negara Islam di Indonesia seperti Kedutaan Besar Kuwait, UEA, OMAN dan lainnya. (7) Mengimplementasikan skenario usaha dengan dimonitoring, dievaluasi dan ditinjau ulang secara periodik untuk suksesnya sebuah usaha wakaf produktif.

\section{Teori Akad}

Kata akad berasal dari kata al-'aqd, bentuk masdar dari kata 'aqada dan jamaknya adalah al-'uqud yang berarti perjanjianatau kontrak(Munawwir, 1997:953).Dalam Ensiklopedi Hukum Islam bahwa kata al-'aqd berarti perikatan, perjanjian, dan permufakatan al-ittifaq(Dahlan, 2001: 63). Akad secara bahasa adalah pertalian yang mengikat.

Menurut Wabbah Zubailiyang dikutip oleh (Djuwaini: 2010:48) akad adalah hubungan keterkaitan antara ijab dan qabulatas diskursus yang dibenarkan oleh syara' dan memiliki implikasi hukum tertentu. Dalam pengertian yang lain akad adalah perikatan antara ijab dengan qabul yang dibenarkan syara' yang menetapkan keridlaan kedua belah 
pihak (Hasbi Ash-Shiddieqy, 1948:21).Sedangkan menurut(Syamsul Anwar: 2007) akad adalah pertemuan ijab dan kabul sebagai penyataan dua pihak atau lebih untuk melahirkan suatu akibat pada objeknya. Dapat dipahami bahwa akad adalah suatu perbuatan yang sengaja dibuat oleh dua orang atau lebih berdasarkan keridhaan masing-masing pihak yang melakukan akad dan memiliki akibat hukum baru bagi mereka yang berakad. Atau hubungan antara ijab dan kabul sesuai dengan kehendak syariat yang ditetapkan adanya pengaruh (akibat) hukum dalam objek perikatan. Rumusan akad mengindikasikan bahwa perjanjian harus merupakan perjanjian kedua belah pihak untuk mengikatkan diri tentang perbuatan yang akan dilakukan dalam suatu hal yang khusus. Akad ini diwujudkan dalam:pertama, dalam ijab dan Kabul, kedua, sesuai dengan kehendak syariat, ketiga, adanya akibat hukum pada objek perikatan.

\section{Landasan Akad}

Dasar dalam akad ini pertama adalah firman Allah dalam alQur'an Surat al-Maidah:1, Surat an-Nisa': 29. Dari ayat ini menegaskan bahwa dalam transaksi perdagangan diharuskan adanya kerelaan kedua belah pihak, atau yang diistilahkannya dengan 'an taradhin minkum.Menurut Quraish Syihab, (2001:413) kerelaan adalah sesuatu yang tersembunyi di lubuk hati, tetapi indikator dan tanda-tandanya dapat terlihat. Ijab dan kabul, atau apa saja yang dikenal dalam adat kebiasaan sebagai serah terima adalah bentuk-bentuk yang digunakan hukum untuk menunjukkan kerelaan. Sedangkan dasar akad dalam kaidah fiqh (Djazuli, 2006:130) berbunyi sebagai berikut:

$$
\text { الأصل في العقد رضى المتعاقدين ونتيجته ماإلتزماه بالتعاقد }
$$

Hukum asal dalam transaksi adalah keridhaan kedua belah pihak yang berakad, hasilnya adalah berlaku sahnya yang diakadkan.

Maksud dari kaidah di atas bahwa keridlaan dalam transaksi ekonomi dan bisnis merupakan prinsip yang utama.Oleh karena itu, transaksi dikatakan sah apabila didasarkan kepada keridlaan kedua belah pihak yang melakukan transaksi. 
Ada beberapa berbedaan pendapat dikalangan ulama tentang rukun akad, namun menurut jumbur ulama rukun akad adalah: 1) $\mathrm{Al}$ 'Aqidain (pihak-pihak yang berakad), 2) Ma'qud 'Alaib (objek akad) 3) Sighat al-'Aqd 4) Tujuan akad

\section{Konsep Pemberdayaan}

Secara konseptual, pemberdayaan atau pemberkuasaan (empowerment) berasal dari kata power (kekuasaan atau keberdayaan). Karenanya ide utama pemberdayaan bersentuhan dengan konsep mengenai kekuasaan (Suharto, 2009). Kekuasaan sering kali dikaitkan dengan kemampuan untuk membuat orang lain melakukan apa yang diinginkan, terlepas dan keinginan dan minat mereka, selanjutnya menurut Suharto dikatakan perberdayaan menunjuk pada kemampuan orang khususnya kelompok rentan dan lemah sehingga mereka memiliki kekuatan atau kemampuan dalam beberapa hal:1) Memenuhi kebutuhan dasarnya sehingga mereka memiliki kebebasan (freedom), dalam arti bukan saja bebas dalam mengemukakan pendapat, melainkan bebas dari kelaparan, bebas dari kebodohan dan bebas dari kesakitan.2)Menjangkau sumbersumber produktif yang memungkinkan mereka dapat meningkatkan pendapatannya dan memperoleh barang-barang dan jasa yang mereka perlukan.3) Berpartisipasi dalam proses pembangunan dan keputusan-keputusan yang mempengaruhi mereka.Pemberdayaan masyarakat juga diartikan sebagai upaya untuk membantu masyarakat dalam mengernbangkan kemampuan sendiri sehingga bebas dan mampu untuk mengatasi masalah dan mengarnbii keputusan secara mandiri. Dengan demikian pemberdayaan masyarakat ditujukan untuk mendorong terciptanya kekuatan dan kemampuan lembaga masyarakat untuk secara mandiri mampu mengelola dirinya sendiri berdasarkan kebutuhan masyarakat itu sendiri serta mampu mengatasi tantangan persoalan dimasa yang akan datang.

Pemberdayaan masyarakat tidak dapat berdiri sendiri tanpa memperhatikan potensi dari sumber daya manusianya, karena sumber daya manusia ini menjadi subjek yang paling vital dalam upaya pelaksanaan pemberdayaan masyarakat. Setidaknya menurut ada tiga jenis kekuatan yang patut diperhatikan dalam 
upaya pemberdayaan masyarakat ditinjau dari potensi sumber daya manusianya, antara lain:1) Kekuatan Pendorong (motivational forces). Dicirikan dengan orang-orang yang tidak puas dengan kondisi yang ada dan mempunyai perasaaan adanya sesuatu yang belum dimiliki secara hakejiwaan.Disinilah peran lembaga zakat dalam menumbuhkan sisi positif individu dan komunitas.2) Kekuatan Bertahan (resistance forces). Kekuatan ini bertujuan mempertahankan sesuatu yang telah ada di masyarakat. Ciri-cirinya antara lain apatis, tidak mudah percaya terhadap pihak luar dan rasa takut yang tinggi dan lebih suka mempertahankan apa yang telah dimiliki.3) Kekuatan Pengganggu (interference forces). Kekuatan ini muncul karena masyarakat saling bersaing untuk dapat dukungan masyarakat dalam proses pembangunan. Umumnya kekuatan ini menginkan ketidakkompakan atau perpecahan.

\section{Metode Penelitian}

Penelitian ini merupakan penelitian field research dengan metode kualitatif.Dengan mengambil objek penelitian biro haji dan umroh Al Mabrur Pondok Pesantren Ta'mirul Islam Surakarta yang terletak di Jl. KH.Samanhudi No 3 Tegalsari Bumi Laweyan Surakarta.Jenis data kualitatif yang digunakan bersumber dari sumber primer dan sumber sekunder.Berupa catatan hasil wawancara dan observasi lapangan.Sedangkan data sekunder hasil dari studi pustaka.Dalam metode pengumpulan data menggunakan teknik, observasi, wawancara dan dokumentasi. Analisa penelitian ini menggunakan analisis SWOT. Teknik akan dilakukan untuk memetakan isu atau faktor strategis adalah analisis SWOT (Strength Weakness Opportunity Threat Analysis), sehingga dapat diketahui isu atau faktor-faktor strategis yang perlu dikembangkan dimasa yang akan datang.

\section{Analisis}

\section{Deskripsi Filosofi Umroh Wakaf}

Biro Haji dan Umroh Al Mabrur Pondok Pesantren Ta'mirul Islam Surakarta dalam melaksanakan programnya memilih manajemen marketing yang inovatif, menggabungkan antara 
model akad tijari dan aqad tabarru dalam program umroh wakaf. Artinya, menggabungkan akad tijari, yang beorintasi profit, melalui program umroh dan akad tabarru, yang berorientasi non profit, melalui program wakaf. Profit di sini, dimaknai dengan keuntungan yang tidak hanya dimiliki oleh pengelola (Biro Haji dan Umroh Al Mabrur Pondok Pesantren Ta'mirul Islam Surakarta),melainkan juga memiliki nilai manfaat bagi yang bersangkutan, menjalankan umroh. Nilai keuntungan inilah yang selanjutnya dikelola dalam program wakaf, oleh Biro Haji dan Umroh Al Mabrur Pondok pesantren Ta'mirul Islam Surakarta atas kesepakatan yang telah dibuat bersama.

Kesepakatan ini dibuat di awal, saat seseorang akan melaksanakan ibadah umroh. Artinya, ketika seseorang datang untuk mendaftar umroh pada Biro Haji dan Umroh Al Mabrur Pondok Pesantren Ta'mirul Islam Surakarta, secara otomatis yang bersangkutan sudah terdaftar sebagai calon wakifProses selanjutnya adalah, mengenalkan program wakaf pada jamaah umroh tersebut. Dimana diketahui bahwa kegiatan wakaf pada umumnya adalah mengambil nilai manfaat atas harta yang dikeluarkan oleh wakif untuk sedekah. Melalui kegiatan umroh wakaf ini, seseorang yang berumroh dapat sekaligus menjadi wakif atas nilai manfaat dari kegiatan umroh yang dilaksanakan. Dengan kata lain, individu dapat melaksanakan dua kegiatan ibadah sekaligus, yaitu umroh dan wakaf.

Hanya saja, nilai wakaf yang dikeluarkan akan dihitung sebelum keberangkatan umroh. Artinya, pendaftar umroh setelah membayar biaya umroh dan dikurangi biaya operasional yang dibutuhkan, sisa pembayaran inilah yang disebut nilai wakaf. Sisa ini sudah dapat diperhitungkan sebelum keberangkatan jamaah umroh. Dan selanjutnya akan dihitung oleh Biro Haji dan Umroh Al Mabrur Pondok Pesantren Ta'mirul Islam Surakarta sebagai nilai wakaf perorangan.

Nilai wakaf dari perorangan masing-masing jamaah umroh akan dikumpulkan secara kolektif seluruh kelompok jamaah umroh yang berangkat secara bersamaan. Hasil nilai wakaf satu kelompok umroh inilah yang dijadikan dasar penentuan jumlah nilai wakaf yang disalurkan dan dikelola oleh Biro Haji dan Umroh Al Mabrur. 
Melalui inovasi marketing yang dikembangkan Biro Haji dan Umroh Al Mabrur ini ternyata membuahkan hasil positif. Hal ini dapat diperkuat dari hasil wawancara yang kami lakukan dengan Direktur Umum Biro Haji dan Umroh Al Mabrur Pondok Pesantren Ta'mirul Islam Surakarta, banyak dari para calon jamaah yang telah membaca brosur dan papan pengumuman mengira bahwa program tersebut adalah program umroh dari hasil wakaf seseorang. Namun program tersebut adalah program menunaikan ibadah umroh yang didalamnya termasuk program wakaf tunai.

Persamaan persepsi istilah Wakaf Umroh inilah yang perlu digarisbawahi untuk pelaksanaan program wakaf tunai berbasis umroh, agar dapat terus dikembangkan dan direspon secara luas. Bukan pada penawaran pelaksanaan ibadah umroh dan wakaf, yang terkesan penggabungan pelaksanaan dua ibadah sekaligus. Melainkan adanya kesadaran individu, atas kemampuan ekonomi yang dimiliki melalui pelaksanaan umroh, dan atas nilai harta yang dimiliki, jamaah umroh tersebut juga dapat menjadi wakif. Pihak Biro Haji dan Umroh Al Mabrur Pondok Pesantren Ta'mirul Islam Surakarta, hanya sebagai mediator bagi seseorang yang ingin melaksanakan ibadah umroh dan memiliki nilai harta yang cukup untuk diwakafkan.

\section{Karakteristik Wakaf Tunai Jamaah}

Besarnya wakaf yang akan dikeluarkan tidak dapat ditentukan secara nominal di depan, artinya besarnya wakaf tunai tidak ditentukan di awal ketika jamaah mendaftar program umroh, akan tetapi besarnya wakaf ditentukan setelah semua biaya operasional umroh dikeluarkan. Dengan kata lain, nilau wakaf tunai diambil dari sisa biaya operasional umroh, atau nilai keuntungan yang ada. Dari nilai keuntungan tersebut, $70 \%$ dikelola Biro Haji dan Umroh Al Mabrur Pondok Pesantren Ta'mirul Islam Surakarta untuk pemegang saham dan operasional kantor, sedangkan 30\% nya digunakan sebagai nilai wakaf. Nilai wakaf tunai ini akan di wakafkan atas nama jamaah umroh langsung ke Pondok Pesantren Ta'mirul Islam. Nilai wakaf perorangan, diperhitungkan secara kolektif satu kelompok keberangkatan umroh, dan dikelola oleh Biro Haji dan Umroh Al Mabrur Pondok Pesantren Ta'mirul Islam Surakarta. 
Tehnis penyerahan nilai wakaf umroh ini, secara seremonial dilaksanakan sebelum jamaah umroh diberangkatkan dari Pondok Pesantren Takmirul Islam Surakarta, yang diikuti dengan doa bersama dan dipimpin oleh Pimpinan Pondok.Dengan demikian nilai wakaf jamaah umroh yang berangkat saat itu, secara resmi sudah diterima oleh Pondok Pesantren Takmirul Islam Surakarta, untuk pengembangan Pondok.

Semakin banyak jamaah yang ikut serta dalam program umroh, maka besarnya atau prosentase wakaf tunai dari jamaah juga akan semakin besar. Artinya kebersamaan jamaah dalam fungsinya mempengaruhi besarnya wakaf tunai yang akan dikeluarkan.Nilainilai kebajikan yang telah dikeluarkan jamaah dalam program wakaf tunai berbasis umroh tentu menjadi terobosan baru dan dapat dijadikan model yang terbarukan dalam pemberdayaan umroh.

\section{Manajemen Pengelolaan Wakaf Tunai Berbasis Umroh}

Biro Haji dan Umroh Al Mabrur adalah salah satu lembaga biro perjalanan Haji dan Umroh berada di bawah Yayasan Pondok Pesantren Ta'mirul Islam Surakarta. mempunyai visi yaitu Berpartisipasi Mengembangkan Wisata Ruhani.Skema Proses Umroh Wakaf di Biro Perjalanan Haji dan Umroh Ta'mirul IslamJamaah mendaftarkan Program Umroh Wakaf di Biro Haji dan Umroh Al Mabrur, sebelum berangkat ibadah umroh, perwakilan jamaah menyerahkan wakaf tunai kepada Pimpinan Pondok Pesantren Ta'mirul Islam yang kemudian digunakan untuk pengembangan pondok.Setelah Wakaf tunai diterima dan selanjutnya di pergunakan untuk pengembangan Pondok Pesantren Ta'mirul Islam.Kelengkapan administrasi dan kesepakatan kaitannya dengan wakaf umroh juga dijelaskan dari awal, untuk membangun kepercayaan antara pihak pengelola dan calon jamaah umroh.

Secara teknis jumlah wakaf tunai yang dikeluarkan kelompok jamaah umroh tersebutdiperoleh dari keuntungan (sisa) atas total biaya yang dikeluarkan. Skema alokasi dana wakaf tunai dapat dilihat pada gambar di bawah ini. 


\section{Alokasi Dana Wakaf Tunai Berbasis Umroh}

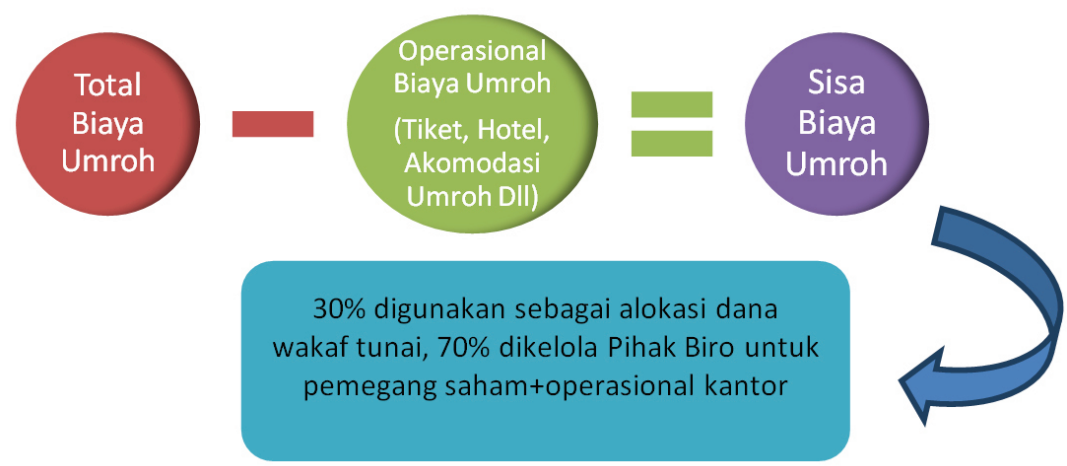

Total Biaya Umroh, dikeluarkan oleh jamaah umroh dan diberikan kepada pihak Biro Haji dan Umroh Al Mabrur Pondok Pesantren Ta'mirul Islam dan menghitung biaya operasional selama perjalanan umroh, terkait dengan hotel, tiket dan biaya operasional lainnya.Selisih antara biaya umroh dikurangi biaya operasional, disebut dengan sisa biaya umroh (keuntungan), yang akan digunakan untuk alokasi wakaf umroh secara tunai dengan prosentase :30\% dari sisa biaya umroh digunakan untuk wakaf tunai, $70 \%$ dari sisa biaya umroh dikelola Pihak Biro untuk pemegang saham dan biaya operasional kantor.

Nilai prosentase untuk alokasi wakaf sebesar 30\% dari sisa biaya (keuntungan). Sedangkan 70\% sisa biaya dikelola oleh Pihak Biro Haji dan Umroh Al Mabrur Pondok Pesantren Ta'mirul Islam, untuk digunakan sebagai operasional kantor dan profit share ke pemegang saham. Prosentase ini sudah diketahui dan disepakati antara pihak pengelola dengan para jamaah umroh. Hanya saja untuk nominal biaya operasional umroh biasanya berbeda di tiap keberangkatan, disesuaikan dengan nilai tukar rupiah terhadap dolar Amerika yang berlaku saat itu, sehingga nilai ini juga berpengaruh pada besar kecilnya nilai wakaf yang dikeluarkan di setiap kelompok jamaah umroh.

Wakaf tunai setelah terkumpul kemudian diserahkan secara langsung kepada Pimpinan Pondok Ta'mirul Islam melalui perwakilan jamaah. Dalam sebuah acara doa bersama pelepasan jamaah dan dipergunakan untuk dana pengembangan Pondok Ta'mirul Islam. 


\section{Gambar 1}

Manajemen Pengelolaan Wakaf Berbasis Umroh.

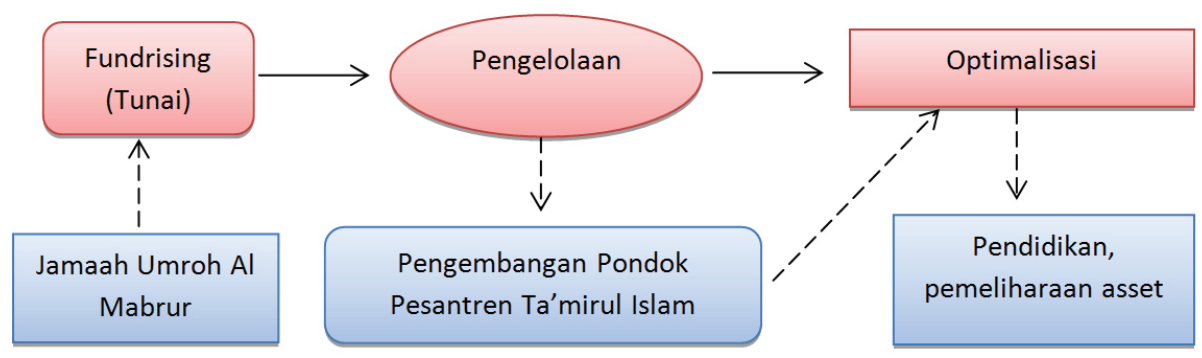

Pengelolaan dan optimalisasi dana wakaf tunai mempunyai nilai manfaat yang fleksibel dan sangat besar, dapat dijadikan instrumen peningkatan kesejahteraan umum terutama di Pondok Pesantren Ta'mirul Islam. Mengingat investasi dana wakaf adalah dana public, selain memiliki nilai ibadah berupa pahala dari Allah SWT, juga harus bermanfaat bagi pembangunan asset di lingkungan Pondok Pesantren Ta'mirul Islam, dengan dibangunnya sarana pendidikan dan asrama bagi santri.

Data Jumlah Jamaah Umroh Juni 2013 - Mei 2014

\begin{tabular}{ccc}
\hline Jamaah & Tanggal & $\begin{array}{c}\text { Jumlah } \\
\text { Jamaah }\end{array}$ \\
\hline I & 1 - 9 Juni 2013 & 19 \\
II & 2 - 10 Januari 2014 & 15 \\
III & 15 -23 Februari 2014 & 30 \\
IV & $23-$ 31 Maret 2014 & 11 \\
V & 17 - 25 April 2014 & 21 \\
VI & 15 - 23 Mei 2014 & 35 \\
VII & 23 - 31 Mei 2014 & 45 \\
& Jumlah Jamaah & 176 \\
\hline
\end{tabular}




\section{Analisis SWOT Dalam Manajemen Pengelolaan Wakaf Umroh}

Lahirnya program wakaf umroh yang dikembangkan oleh Pihak Biro Haji dan Umroh Al Mabrur, merupakan hasil dari kecermatan pihak Pondok Pesantren Ta'mirul Islam dalam mengambil peluang pelaksanaan ibadah wakaf berbasis umroh. Dalam pengembangan profesional pengelolaan wakaf, dimana daya tarik wakaf sudah mulai dilirik untuk diberdayakan secara profesional -produktif.

\section{Strength (Kekuatan)}

Faktor yang menjadi kekuatan terbentuknya program wakaf umroh adalah : 1) Keberadaan Pondok Pesantren Ta'mirul Islam sebagai pusat informasi tentang keislaman (center of Islamic information), dikota Surakarta, dalam memberikan informasi tentang ibadah haji, umroh dan wakaf, yang sesuai dengan syariat Islam. 2) Almarhum KH. Naharussurur Pemimpin Pondok Pesantren Ta'mirul adalah figure tokoh Islam, sehingga mampu memberikan pengaruh positif di lingkungan Pondok Pesantren Ta'mirul Islam dan Kota Surakarta secara umum. 3) Pondok Pesantren Ta'mirul Islam mempunyai Sumber Daya Manusia (SDM) yang memadai dan handal dalam pemahaman syariat Islam, berhubungan dengan manasik haji, umroh dan wakaf. SDM yang kreatif, inovatif dan futuristic inilah yang mampu menjalankan pengembangan wakaf tunai kepada masyarakat pada umumnya.

\section{Weakness (Kelemahan)}

Pengembangan program wakaf umroh, dalam praktiknya memiliki kelemahan sebagai berikut: 1) Minimnya biro travel haji dan umroh yang memiliki pengalaman dan pemahaman tentang pelaksanaan haji dan umroh. 2) Minimnya biro travel haji dan umroh yang memiliki semangat philantropi melalui program wakaf. 3) Minimnya sumber daya manusia yang memiliki pemahaman bisnis Islami, sehingga biro travel yang ada dijalankan dengan system profit oriented bukan bagi hasil.

\section{Opportunity (Kesempatan)}

Lahirnya program Wakaf Umroh ini merupakan manifestasi dari peluang yang tersebut di bawah ini: 1) Adanya UU No. 40 
2002 tentang pengelolaan wakaf tunai menjadi pijakan strategis untuk mengelola wakaf tunai secara professional dan modern. 2) Belum banyaknya Biro Travel Haji dan Umroh di Surakarta yang menggunakan model wakaf umroh, menggabungkan akad tijari dan akad tabarru.3) Tersedianya Sumber Daya Manusia yang memadai untuk pengembangan usaha di bidang Biro Haji dan Umroh, agar dapat mengakomodir kebutuhan yang ada.

\section{Threat (Tantangan)}

Praktek pengembangan program wakaf umroh, dalam perjalanannya menghadapi beberapa tantangan sebagai berikut: 1) Menjamurnya Biro Travel Haji dan Umroh yang menawarkan biaya lebih rendah, tanpa memberikan pelayanan yang maksimal. 2) Biro Haji dan Umroh Al Mabrur Pondok Pesantren Ta'mirul Islam, termotivasi untuk terus memberikan pelayanan maksimal dalam pengembangan produk wakaf umroh.

\section{Analisis Kesesuaian Syariah}

Melalui metode comparation analysis, pelaksanaan Wakaf Tunai Berbasis Umroh diperiksa kembali kecocokannya dengan aspek pembanding, yaitu rukun, syarat wakaf, dan ketentuan MUI, untuk kemudian diketahui apakah program Wakaf Tunai berbasis Umroh sudah sesuai syariah atau belum. Untuk memudahkan analisis, kesesuaian aspek pembanding dibuat dalam bentuk tabel, dan selanjutnya diberi penilaian.

\section{Table 1}

\section{Comparation Analysis terhadap Rukun dan Syarat Syariah}

\begin{tabular}{lll}
\hline \multirow{2}{*}{ No } & \multirow{2}{*}{ Aspek Perbandingan Syariah } & \multicolumn{2}{l}{ Kesesuaian } \\
& Ya Tidak \\
\hline
\end{tabular}

\section{A Rukun Wakaf}

1. Orang yang berwakaf (al-waqif)

2. Benda yang diwakafkan (al-mauquf)

3. Penerima manfaat wakaf (al-mauquf 'alaihi)

4. Lafadz atau ikrar wakaf (sighah) 


\section{B Syarat Orang yang Berwakaf (Waqif)}

1. Memiliki harta secara penuh

2. Berakal

3. Baligh

4. Mampu bertindak secara hukum (rasyid)

C Syarat Harta Wakaf

1. Berharga

2. Diketahui jumlah dan kadarnya

3. Dimiliki penuh oleh waqif

4. Harta itu mestilah berdiri sendiri (ghaira shai').

D Syarat Penerima Wakaf

Tidak tertentu (ghaira mu'ayyan)

Akad Wakaf Tunai Berbasis Umroh ditujukan

$\sqrt{ }$ untuk ghaira mu'ayyan.

\section{E Syarat Sighah}

1. Kata-kata yang menunjukkan kekalnya (ta'bid)

2. Segera (tanjiz), tanpa syarat tertentu

3. Bersifat pasti

4. Tidak diikuti oleh syarat yang membatalkan

Untuk memperkuat hasil analisis, selain perbandingan secara subtansi syariah diperlukan pula perbandingan dari segi hukum negara yang tertuang dalam Fatwa MUI tanggal 11 Mei tahun 2002 mengenai wakaf uang, tampak pada tabel dibawah ini. 
Tabel 2.

Comparation Analysis terhadap Fatwa MUI

\begin{tabular}{cll}
\hline \multirow{2}{*}{ No } & \multicolumn{1}{c}{ Aspek Perbandingan Fatwa MUI } & \multicolumn{2}{c}{ Kesesuaian } \\
Ya & Tidak \\
\hline $1 \quad \begin{array}{l}\text { Wakaf uang (cash wakaf/ waqf al-nuqud) } \\
\text { adalah wakaf yang dilakukan seseorang, } \\
\text { kelompok orang, lembaga atau badan hukum } \\
\text { dalam bentuk uang }\end{array}$ & $\sqrt{ }$ \\
2 & $\begin{array}{l}\text { Termasuk ke dalam pengertian uang adalah } \\
\text { surat-surat berharga }\end{array}$ & $\sqrt{ }$ \\
3 & Waqaf uang hukumnya jawaz (boleh) & $\sqrt{ }$ \\
& $\begin{array}{l}\text { Wakaf uang hanya boleh disalurkan dan } \\
\text { digunakan untuk hal-hal yang dibolehkan } \\
\text { secara syar'i. Nilai pokok wakaf uang harus } \\
\text { dijamin kelestariannya, tidak boleh dijual, } \\
\text { dihibahkan dan atau diwariskan. }\end{array}$ \\
\hline
\end{tabular}

Berdasarkan hasil analisis yang dilakukan, semua komponen pembanding syariah memiliki kesesuaian dengan mekanisme Wakaf Tunai Berbasis Umroh.Selain itu jika dibandingkan dengan Fatwa MUI, semua aktivitas Wakaf Tunai Berbasis Umroh tidak ada yang bertentangan.Artinya secara substansi dan fatwa, pelaksanaan Wakaf Tunai Berbasis Umroh di Pondok Pesantren Ta'mirul Islam sudah sesuai dengan syariah.

\section{Kesimpulan}

Munculnya program wakaf tunai berbasis umroh di Pondok Pesantren Ta'mirul Islam adalah sumbangan pemikiran Pimpinan Pondok Ta'mirul Islam untuk membuat sebuah amal usaha yang mempunyai tujuan membantu pengembangan Pondok Ta'mirul Isalm Surakarta. Lembaga ini kemudian di beri nama Biro Haji Umroh Al Mabrur. Biro perjalanan haji umroh yang telah berdiri menawarkan program umroh wakaf, bertujuan memberikan 
pelayanan jamaah untuk menunaikan ibadah umroh atau haji serta memberikan kesempatan untuk mengeluarkan wakaf tunai secara langsung.Amal usaha pondok ini memiliki manajemen marketing yang inovatif, menggabungkan antara model akad tijari dan aqad tabarru dalam program umroh wakaf. Artinya, menggabungkan akad tijari, yang beorintasi profit, melalui program umroh dan akad tabarru, yang berorientasi non profit, melalui program wakaf. Melaui program umroh wakaf inilah yang mengakomodir pemanfaatan nilai harta seseorang dengan pelaksanaan dua ibadah sekaligus, yaitu ibadah umroh dan ibadah wakaf.Sedangkan besarnya wakaf yang akan dikeluarkan tidak dapat ditentukan secara nominal di depan, artinya besarnya wakaf tunai tidak ditentukan di awal tetapi ditentukan setelah semua biaya operasional umroh dikeluarkan. nilai wakaf tunai diambil dari sisa biaya operasional umroh, atau nilai keuntungan yang ada. 70\% dikelola Biro Haji dan Umroh Al Mabrur untuk pemegang saham dan operasional kantor, sedangkan $30 \%$ nya digunakan sebagai nilai wakaf. Nilai wakaf tunai ini di wakafkan atas nama jamaah umroh langsung ke Pondok Pesantren Ta'mirul Islam. Nilai wakaf perorangan, diperhitungkan secara kolektif satu kelompok keberangkatan umroh, dan dikelola oleh Biro Haji dan Umroh Al Mabrur Pondok Pesantren Ta'mirul Islam Surakarta. Semakin banyak jamaah yang ikut serta dalam program umroh, maka besarnya atau prosentase wakaf tunai dari jamaah juga akan semakin besar. Mengingat investasi dana wakaf adalah dana public, selain memiliki nilai ibadah berupa pahala dari Allah SWT, juga harus bermanfaat bagi pembangunan asset di lingkungan Pondok Pesantren Ta'mirul Islam, Yang lebih penting lagi investasi dana wakaf mengoptimalisasikan fungsi harta wakaf yang berguna sebagai prasarana untuk mengembangkan kualitas hidup di lingkungan Pondok dan masyarakat luas pada umumnya. Ada kenaikan jumlah jamaah yang cukup signifikan, pencapaian ini tentunya, atas usaha keras seluruh pihak Biro Umroh Al Mabrur, untuk mengenalkan program umroh wakaf kepada masyarakat luas, dan kepercayaan masyarakat itu sendiri kepada Pondok Pesantren Ta'mirul Islam sebagai pengelola dana wakaf umroh. Dalam Analisis kesesuaian syariah dilakukan dengan menggunakan metode comparation analysis. Dengan diperiksa kembali kecocokannya 
dengan aspek pembanding, yaitu rukun, syarat wakaf, dan ketentuan MUI.Berdasarkan hasil analisis yang dilakukan, semua komponen pembanding syariah memiliki kesesuaian dengan mekanisme Wakaf Tunai Berbasis Umroh.Selain itu jika dibandingkan dengan Fatwa MUI, semua aktivitas Wakaf Tunai Berbasis Umroh tidak ada yang bertentangan.Artinya secara substansi dan fatwa, pelaksanaan Wakaf Tunai Berbasis Umroh sudah sesuai dengan syariah.

\section{Daftar Pustaka}

A.Djazuli.2006.Kaidah-KaidahFikih;Kaidah-kaidah Hukum Islam dalam Menyelesaikan Masalah-masalah yang Praktis. Jakarta:Kencana Abu al-Fath, Ahamd.1913. Kitab al-Mu'amalat fi asy-Syariah al Islamiyyah wa al Qawanin al-Mishriyyah.Mesir: Maktabah al-Busfir.

Al-Kabisi, Muhammad Abid Abdullah. 2004. Hukum Wakaf. Diterjemahkan oleh Ahrul Sani Fathurrohman (et.al.), Jakarta, IIMaN Press.

Anshori, Abdul Ghafur. 2006.Hukum dan Praktik perwakafan di Indonesia. Yogyakarta:Pilar Media.

Anwar, Syamsul, 2007 Hukum Perjanjian Syariah. Jakarta: PT Raja Grafindo Persada. , 1996.Hukum Perjanjian Dalam Islam; Kajian

TerhadapMasalah Perizinan (Toestemming) dan CacatKehendak (Wilsgerbrek)", Laporan Penelitian Pada Balai Penelitian P3M Institut Agama Islam Negeri Sunan Kalijaga Yogyakarta. , 2007Hukum Perjanjian Syariah, Studi tentang Teori Akad dalam Fikih Muamalat.Jakarta: Rajawali Pers

Ash-Shieddieqy, T.M. Hasbi. 1984. Pengantar Fiqh Muamalah. Jakarta: PT. Bulan Bintang

Az-Zuhayli, Wahbah, t.th.,al-Figh al-Islami wa Adillatuhu, Beirut: Dar al-Fikr 
Dahlan, Abdul Aziz. 2001. Ensiklopedi Hukum Islam. Jakarta: PT Ichtiar Baru van Hoeva.

Djuwaini,Dimyauddin. 2010. Pengantar Fiqh Muamalah. Yogyakarta: Pustaka Pelajar.

Fahmi Medias, Wakaf Produktif Dalam Perspektif Ekonomi Islam, Jurnal La-Riba Vol IV No.1 Juli 2010

Huda, Miftahul. 2011. Mekanisme Kerja Bersama Antara Nazir dan Lembaga Keuangan Syariah Penerima Wakaf Uang (LKSPWU) Dalam Menggalang Wakaf Uang Perspektif Manajemen Fundrising. Jurnal Asy-Syir'ah, Vol. 45, No. I, 2011

Ihksanudin.2012. Optimalisasi Wakaf Produktif Bagi Lembaga

Pendidikan Dan Ormas Islam Di Indonesia.Jurnal Mukaddimah, Vol. 18, No. 1.

M. Quraish Shihab. 2001. Tafsir Al-Misbah; Pesan, Kesan dan Keserasian Al-Qur'an",Ciputat: Lintera Hati.

Munawwir,A.Warson. 1997. Kamus Al-Munawwir Arab-Indonesia Lengkap. Surabaya: Pustaka Progressif.

Rahardjo,Satjipto 1986. Hukum dan Masyarakat.Bandung: Angkasa

Saidi, Zaim, Kemitraan Investasi Wakaf Produktif, Makalah, Jakarta: Tabung Wakaf Indonesia.

Sudarsono, Heri. 2004. Bank dan Lembaga Keuangan Syariah: Deskripsi dan Ilustrasi.Edisi Kedua. Ekonisia, Yogyakarta.

Suhairi. 2011. Implementasi Wakaf Uang (Studi Terhadap Persepsi Umat Islam Kota Metro Serta Kesiapan Bank Syariah Mandiri Dan Kementerian Agama Kota Metro). Jurnal Tapis, Vol. 11, No. 01.

Suharto, E. 2009. Membangun Masyarakat Memberdayakan Rakyat. Bandung: Refika Aditama. 